\title{
Kemampuan Mengkonstruksi Bukti Geometri Mahasiswa Calon Guru Matematika Pada Perkuliahan Geometri
}

\author{
Samsul Maarif ${ }^{1 *}$, Wahyudin ${ }^{2}$, Fiti Alyani ${ }^{3}$, Trisna Roy Pradipta ${ }^{4}$ \\ ${ }^{1,3,4}$ Program Studi Pendidikan Matematika, Universitas Muhammadiyah Prof. DR. HAMKA \\ ${ }^{2}$ Departemen Pendidikan Matematika, Universitas Pendidikan Indonesia \\ *samsul_maarif@uhamka.ac.id
}

\begin{abstract}
Abstrak
Penelitian ini bertujuan untuk menganalisis dan mendeskripsikan kemampuan mengkonstruksi bukti mahasiswa calon guru matematika pada perkualiahan geometri dasar topik konsep kesajajaran, segitiga, dan kekongruenan dua buah segitiga. Penelitian ini menggunakan metode deskriptif kualitatif yang melibatkan 35 mahasiswa calon guru matematika di Universitas PGRI Semarang. Hasil penelitian ini menunjukan bahwa (1) $28 \%$ mahasiswa membuat sketsa diagram dan menggunakan label geometri secara tepat pada bukti yang telah dikonstruksi; (2) $28,57 \%$ mahasiswa memiliki langkah awal pembuktian secara tepat; (3) $28,57 \%$ mahasiswa dapat menentukan konjektur dengaan tepat yang mengarah pada bukti yang benar; (4) $25,71 \%$ mahasiswa tepat dalam menyusun argumentasi bukti sesuai dengan postulat dan teorema yang benar; (5) $25,71 \%$ proses alur berpikir yang digunakan mahasiswa runtut mengarah pada bukti yang benar; dan (6) 22,86\% mahasiswa menguasai teorema dan konsep yang digunakan dalam meyusun bukti.
\end{abstract}

Kata kunci: bukti geometri, mengkonstruksi bukti geometri, pembuktian

\begin{abstract}
This study aims to analyze and describe the ability to construct proofs of perspective teacher mathematics students in basic geometrical lectures on the concepts of alignment, triangles, and concordance of two triangles. This research uses a descriptive qualitative method involving 35 prospective mathematics students at the Universitas PGRI Semarang. This study uses a qualitative descriptive method involving 35 students. The results of this study show that: (1) $28 \%$ of students sketched diagrams and used geometric labels appropriately on the constructed evidence; (2) $28.57 \%$ of students have the correct initial step of proof; (3) $28.57 \%$ of students can determine the exact conjecture that leads to the correct proof; (4) $25.71 \%$ of students are correct in compiling proof arguments by the correct postulate and theorem; (5) $25.71 \%$ of the thought flow process used by coherent students leads to valid evidence; and (6) $22.86 \%$ of students mastered theorems and concepts used in compiling constructing proof.
\end{abstract}

Keywords: construct the proof of geometry, geometry proof, proof

Received: April 5, 2020 / Accepted: June 24, 2020 / Published Online: July 30, 2020

\section{Pendahuluan}

Proses ekplorasi terhadap hasil kerja mengkonstruksi bukti lazimnya dilakukan di dalam setiap proses pembelajaran. Hal tersebut dilakukan oleh seorang dosen untuk mengetahui seberapa besar proses pembelajaran sudah dilakukan dengan baik, sehingga dapat dilakukan tindak lanjut untuk pembelajaran selanjutnya. Dalam perkuliahan geometri dasar proses 
ekplorasi terhadap kemampuan mengkonstruksi bukti menjadi bagian penting, karena materi yang dipelajari banyak berhubungan dengan teorema-teorema yang harus dibuktikan (Pegg, Gutiérrez, \& Huerta, 1998).

Peran pembuktian bagi seseorang pembelajar matematika sebagai penentu tingkat kematangan dalam proses berpikir matematika (Otten, Gilbertson, Males, \& Clark, 2014). Hal tersebut dikarenakan pembuktian yang mengahruskan seseorang menggunakan pengetahuan matematik dan menulisakanya dalam argumen yang logis membutuhkan proses berpikir matematik yang komprehensif (Cervantes-Barraza, Hernandez Moreno, \& Rumsey, 2020). Oleh karena itu, para pemerhati matematika banyak membuat ide dan gagasanya dalam bentuk kajian ataupun penelitian guna mengopotimalkan proses pembuktian dalam proses pembelajaran matematika.

Berbagai hasil penelitian menyimpulkan bahwa proses pembelajaran tentang pembuktian terhadap mahasiswa diperguruan tinggi belum mencapai pada tahapan yang optimal sesuai harapan (Heinze \& Reiss, 2002; Leech \& Onwuegbuzie, 2007; Michael, Gagatsis, \& Gagatsis, 2013; Kuusi, Mingione, \& Nyström, 2014; Daguplo \& Development, 2014; Jones, 2010; Bieda, Ji, Drwencke, \& Picard, 2014; Azrou \& Khelladi, 2019). Hasil penelitian Reiss dan Renkl (2002) mengungkapkan bahwa masih banyak keterbatasan mahasiswa dalam proses pembuktian (Reiss \& Renkl, 2002). Selanjutnya Maarif, Perbowo, Noto, dan Harisman (2019) menyimpulkan hasil penelitiannya bahwa keterbatasan mahasiswa dalam mengkonstruksi bukti geometri diantaranya kesulitan membuat sketsa diagram dengan label geometri yang tepat dan kesulitan dalam mengkonstruksi konjektur dalam menuliskan bukti formal. Dari hal tersebut, perlu kiranya kita mengoptimalakan proses mengekplorasi kemampuan mengkonstruksi bukti guna meningkatkan kemampuan pembuktian geometri.

Gagasan awal dalam mengkonstruksi pembuktian matematis ditandai dengan adanya langkah awal untuk memulai menyusun bukti (Ozturk, 2020). Langkah awal suatu pembuktian diartikan sebagai gagasan awal dalam suatu pernyataan yang akan dijadikan acuan dalam menentukan pernyataan-pernyataan berikutnya (Sommerhoff \& Ufer, 2019). Langkah awal yang benar akan menentukan langkah-langkah selanjutnya dalam proses pembuktian hingga pada suatu kesimpulan bukti yang diharapkan (Isnarto, 2014; Arnawa, Sumarno, Kartasasmita, \& Baskoro, 2007). Hal tersbut menunjukan bahwa dalam mengkonstruksi bukti matematis termasuk didalamnya bukti geometri, langkah awal pembuktian memiliki peranan penting dalam menyusun bukti geometri. 
Kegiatan mengkonstruksi bukti tidak terpisahkan dari kegiatan menentukan konjektur atas solusi bukti yang akan dituliskan (Tripathi, 2020). Magajna (2013) mendefinisikan konjektur sebagai proposisi yang masuk akal atas kebenran yang belum ditetapkan. Hasil penelitian yang dilakuakn Mariotti dan Pedemonte (2019) mengungkapkan hubungan antara argumentasi dan bukti dalam kaitan penyelesaian masalah buktti adalah ketepatan sesorang dalam menentukan konjektur terhadap teorema yang akan digunakan.

Suatu bukti matematika disusun atas argumentasi yang valid dan susunan argumentasi valid tersebut akan menentukan kesahihan bukti tersebut (Jones, 2010). Berdasarakan hubungan antara argumentasi dan bukti, Barraza, Moreno, dan Rumsey (2020) mengungkapakan argumentasi dalam menuliskan bukti sebagai keterampilan yang penting, karena ini merupakan sarana untuk memulai proses pembuktian. Proses membenarkan pernyataan dengan argumentasi yang valid, dapat memberikan pemikiran siswa menuju pada suatu konjektur yang mengarah pada bukti yang diinginkan (Mariotti \& Pedemonte, 2019).

Alur berpikir terhadap suatu bukti dapat diartikan sebagai serangkain ide sesorag yang ditunjukan dalam langkah-langkah atau cara membuktikan terhadap masalah yang akan dibuktikan (Ningrum \& Mega, 2015). Alur berpikir yang logis akan ditunjukan dari adanya keterkaitan antar pernyataan dalam langkah bukti yang telah disusun (Harini \& Oka, 2016). Alur beripikir yang runtut tanpa adanya lompatan logika, akan mudah diterima bagi seseorang untuk memahami bukti yang telah dituliskan (Tripathi, 2020).

Bukti geometri dalam pengertian post-Hilbert modern adalah urutan pernyataan yang didefinisikan secara tepat dalam bahasa formal dengan menggunakan postulat, teorema atau lemma yang telah terbukti sebelumnya (Lindsay, 1998). Pemilihan terhadap postulat dan teorema yang akan digunakan dalam menyusun bukti akan menentukan kebenaran bukti yang diajukan (Magro, 2019). Pemahaman terhadap postulat, teorema dan prinsip-prinsip geometri sangat dibutuhkan dalam kegiatan mengkonstruksi bukti geometri (Maarif, Perbowo, Noto \& Harisman, 2019).

Penelitaian tentang kemampuan pembuktian geometri sudah banyak dilakukan diantaranya kemampuan pembuktian geometri yang menyoroti aspek intuisi dan konjektur (Mariotti \& Pedemonte, 2019); aspek argumentasi (Sommerhoff \& Ufer, 2019; Arnawa, Sumarno, Kartasasmita, \& Baskoro, 2007) aspek mengkonstksi sketsa diagram, pemahaman terhadap konsep dan menuliskan bukti (Maarif, dkk., 2019; Arnawa, Sumarno, Kartasasmita, \& Baskoro, 2007); dan aspek jastifikasi alur berpikir bukti (Jones, 2010). Penelitian-penelitian tersebut belum secara komprehensif memfokuskan pada semua aspek. Ileh karena itu, pada kesempatan ini peneliti mengambil peran untuk mengekplorasi kemampuan pembuktian 
geometri dengan menyatukan semua aspek tersebut yang terangkum pada aspek: 1) sketsa diagram dan label geometri; 2) memanfaatkan konjektur 3) langkah awal pembuktian; 4) alur berpikir yang logis dalam menysun bukti; 5) argumentasi; 6) pemahaman terhadap teorema atau konsep geometri dalam menyusun bukti.

Dari pemaparan di atas perlu kiranya dilakukan proses pendeskripsian terhadap kemampuan mengkonstruksi bukti geometri. Deskripsi hasil kerja kemampuan mengkonstruksi bukti dilakukan untuk mengetahui seberapa jauh kemampuan mahasiswa calon guru matematika dalam mengkonstruksi bukti gometri dalam perkuliahan geometri dasar. Penelitian ini bertujuan untuk mendeskripsikan kemampuan mengkonstruksi bukti geometri yang didasarkan pada enam aspek mengkonstruksi bukti geometri yaitu sketsa diagram dan label geometri; memanfaatkan konjektur; langkah awal pembuktian; alur berpikir yang logis dalam menysun bukti; argumentasi; pemahaman terhadap teorema atau konsep geometri dalam menyusun bukti.

\section{Metode}

Metode yang digunakan pada penelitian ini adalah deskriptif kualitatif. Partisipan yang terlibat pada penelitian ini sebanyak 35 mahasiswa calon guru matematika semester I Universitas PGRI Semarang (UPGRIS). Pemilihan lokasi penelitian didasarkan pada struktur kurikulum lokasi penelitian terdapat mata kuliah Geometri Dasar yang mengakomodir pembuktian geometri sebagai capain proses pembelajaran. Selain itu, pemilihan lokasi penelitian tidak dilakukan pada isntansi asal penulis dengan alasan ada kemungkinan subjek penelitian terhadap persepsi negatif terhadap proses penilaian.

Teknik pengumpulan data dilakukan dengan memberikan tes kemampuan mengkonstruksi bukti terhadap 35 mahasiswa. Data diambil dari hasil pekerjaan mahasiswa terhadap tes kemampauan mengkonstruksi bukti geometri setelah proses perkuliahan berakhir mahasiswa diberikan tes kemampuan mengkonstruksi bukti materi geometri.

Instrumen pada penelitian ini menggunakan tes kemampuan mengkonstruksi bukti geometri. Indikator yang digunakan dalam penyusunan intrumen tersebut mengacu pada: 1) kemampuan membuat sketsa diagram (gambar) dan label geometri dari pernyataan yang akan dibuktikan; 2) kemampuan memanfaatkan konjektur yang telah dikonstruksi 3) kemampuan menentukan langkah awal pembuktian; 4) kemampuan menyusun alur berpikir yang logis; 5) kemampuan menuliskan argumen untuk membuktikan pernyataan; 6) kemampuan memahami dan memanfatkan teorema atau konsep geometri dalam menyusun bukti (Mariotti \& 
Pedemonte, 2019; Arnawa, Sumarno, Kartasasmita, \& Baskoro, 2007; Isnarto, 2014; Bieda, Ji, Drwencke, \& Picard, 2014; Sommerhoff \& Ufer, 2019; Maarif, Perbowo, Noto \& Harisman, 2019). Berikut tes mengkonstruksi bukti geometri yang diberikan kepada mahasiswa dengan mengacu pada keenam indikator yang tidak terpisah.

Buktikan bahwa: Jika pada $\triangle A B C$ sisi $A C$ dan $B C$ masing-masing dikonstruksi segitiga sama sisi yaitu $\triangle A B D$ dan $\triangle B C E$ pada bagian luar $\triangle A B C$, maka $A E \cong D C$.

Proses penilaian terhadap jawaban mahasiswa dilakukan dengan memberikan skor mengikuti rubrik pensekoran yang menacu pada indikator kemampuan mengkonstruksi bukti yang telah disampaikan di atas, tabel 1 menunjukan rubrik pensekoran yang digunakan dalam penelitian.

Tabel 1. Rubrik Pensekoran Kemampuan Mengkonstruksi Bukti Geometri (diadptasi dari Arnawa, Sumarno, Kartasasmita, \& Baskoro, 2007; Middleton, 2009; Masters, 2010)

\begin{tabular}{|c|c|c|}
\hline Aspek & Indikator Pensekoran Kemampuan Mengkonstruksi Bukti Geometri & Skor \\
\hline \multirow{23}{*}{$\begin{array}{l}\text { Kemampuan } \\
\text { Mengkonstruksi Bukti } \\
\text { Geometri }\end{array}$} & Bukti jelas dan secara keseluruhan benar. Penggunaan sketsa diagram dan & \multirow[t]{6}{*}{4} \\
\hline & label geometri sesuai dengan apa yang digunakan dalam bukti. Langkah & \\
\hline & awal pembuktian memiliki koherensi dengan langkah bukti berikutnya. & \\
\hline & Konjektur yang disusun sesuai dengan tujuan bukti. Semua pernyataan & \\
\hline & didukung oleh argumentasi yang tepat. Alur pembuktian disusun secara & \\
\hline & logis. Menggunakan konsep dan teorema yang tepat. & \\
\hline & Buktinya sekitar $80 \%$ benar. Penggunaan sketsa diagram dan label & \multirow[t]{6}{*}{3} \\
\hline & geometri yang sesuai dengan apa yang digunakan dalam bukti. Langkah & \\
\hline & awal pembuktian memiliki koherensi dengan langkah bukti berikutnya. & \\
\hline & Konjektur yang disusun sesuai dengan tujuan bukti. Terdapat sedikit & \\
\hline & kesalahan pada penentuan argumen langkah bukti. Menggunakan konsep & \\
\hline & dan teorema geometri secara benar. & \\
\hline & Setidaknya setengah dari buktinya benar. Penggunaan sketsa diagram dan & \multirow[t]{5}{*}{2} \\
\hline & label geometri sesuai dengan apa yang digunakan dalam bukti. Langkah & \\
\hline & awal benar, tetapi terdapat beberapa langkah yang tidak sesuai. Terdapat & \\
\hline & beberapa konjektur yang disusun tidak sesuai dengan tujuan bukti. & \\
\hline & $\begin{array}{l}\text { Beberapa argumen yang digunakan tidak sesuai. Menggunakan konsep dan } \\
\text { teorema yang tepat. }\end{array}$ & \\
\hline & Kurang dari setengah buktinya benar. Penggunaan sketsa diagram dan & \multirow[t]{5}{*}{1} \\
\hline & simbol sesuai. Kesalahan dalam menentukan langkah awal pembuktian. & \\
\hline & Terdapat langkah pembuktian yang tidak ada. Terdapat argumen yang & \\
\hline & kurang tepat. Terdapat beberapa konsep dan teorema yang digunakan & \\
\hline & dalam pembuktian salah. & \\
\hline & $\begin{array}{l}\text { Tidak menjawab atau bukti yang disusun tidak terkait dengan bukti yang } \\
\text { diharapkan. }\end{array}$ & 0 \\
\hline
\end{tabular}

Analisis data dilakukan dengan menggunakan teknik deskriptif yaitu mendeskripsikan hasil tes kemampuan mengkonstruksi bukti geometri yang kemudian melalui pendekatan kualitatif dilakukan proses analasis terhadap fenomena yang muncul pada jawaban mahasiswa. Jumlah jawaban tes akhir kemampuan mengkonstruksi bukti 35 jawaban mahasiswa. Jawaban mahasiswa diberikan kode R-1 samapai dengan R-35, yang untuk selanjutnya akan dijadikan 
simbol penanda responden pada tiap-tiap buktir item soal. Dengan pendekatan kualitatif dilakukan analisis jawaban mahasiswa dengan memfokuskan pada aspek penggunaan sketsa diagram dan label geometri; pemanfaatan konjektur; langkah awal pembuktian; argumentsai; alur berpikir dan pemahaman terhadap teorema atau konsep geometri yang terkait.

\section{Hasil Penelitian}

Hasil analisis terhadap 35 jawaban mahasiswa merujuk pada kemampuan mongkonstruksi bukti geometri. Kemampuan mengkonstruksi bukti geometri menasarasarkan pada aspek penggunaan sketsa diagram dan label geometri; langkah awal; pemanfaatan konjektur; pembuktian; argumentsai; alur berpikir dan konsep-konsep terkait. Berikut contoh masalah pembuktian geometri dalam tes kemampuan mengkonstruksi bukti yang diberikan kepada mahasiswa. Dari hasil jawaban mahasiswa terhadap soal pembuktian geometri, berikut disajikan persentase keberhasilan mahasiswa dalam mengkonstruksi bukti geometri yang mendasarkan pada aspek-aspek yang telah disebutkan dengan tipe-tipe kesalahan yang terjadi seperti tampak pada tebel 2 berikut.

Tabel 2. Hasil Penilaian Kemampuan Mengkonstruksi Bukti Geometri

\begin{tabular}{|c|c|c|}
\hline Aspek & $\begin{array}{l}\text { Persentase } \\
\text { Keberhasilan } \\
\end{array}$ & Tipe-tipe kesalahan \\
\hline \begin{tabular}{lr}
\multicolumn{2}{l}{ Penggunaan } \\
sketsa diagram \\
dan & label \\
geometri &
\end{tabular} & $28 \%$ & $\begin{array}{l}\text { 1. Tidak lengkap dalam menentukan label pada sketsa diagram dan label } \\
\text { geometri yang telah dikonstruksi } \\
\text { 2. Sketsa diagram yang telah dikonstruksi tidak mencerminkan dengan } \\
\text { informasi yang terdapat dalam maslah yang akan dibuktikan } \\
\text { 3. Tidak dapat mengkonstruksi sketsa diagram dan label geometri dari } \\
\text { masalah yang akan dibuktikan }\end{array}$ \\
\hline Langkah awal & $28,57 \%$ & $\begin{array}{l}\text { 1. Memulai pembuktian dengan mengambil unsur pada sketsa diagram } \\
\text { yang dibuat, tetapi unsur yang diambil tidak memiliki hubungan unsur } \\
\text { yang ada pada kesimpulan akhir bukti } \\
\text { 2. Langkah awal bukti sudah benar, akan tetapi terjadi kesalahan } \\
\text { mengambil syarat cukup konsep kekongruaenan segitiga } \\
\text { 3. Langkah awal tidak memiliki keterkaitan dengan bukti yang benar }\end{array}$ \\
\hline $\begin{array}{l}\text { Penggunaan } \\
\text { konjektur }\end{array}$ & $28,57 \%$ & $\begin{array}{l}\text { 1. Konjektur yang diambil kurang tepat akibat ketidakpahaman terhadap } \\
\text { syarat cukup dua segitiga saling kongruen. } \\
\text { 2. Konjektur yang diambil tidak sesuai dengan sketsa diagram yang telah } \\
\text { dibuat } \\
\text { 3. Sudah dapat menentukan konjektur dengan tepat, akan tetapi tidak } \\
\text { dapat memanfaatkanya untuk menentukan konjektur selanjutnya yang } \\
\text { mengarah pada bukti yang diharapkan. }\end{array}$ \\
\hline Argumentsai & $25,71 \%$ & $\begin{array}{l}\text { 1. Argumentasi yang telah disusun tidak disertai alasan logis sehingga } \\
\text { terjadi kesalahan bukti } \\
\text { 2. Argumen yang telah disusun tidak ada hubunganya dengan bukti yang } \\
\text { dituju }\end{array}$ \\
\hline Alur berpikir & $25,71 \%$ & $\begin{array}{l}\text { 1. Alur bukti sudah runtut, akan tetapi karena ada kesalahan dalam } \\
\text { menentukan syarat cukup dua segitiga saling kongruan, maka bukti } \\
\text { tidak mengarah pada bukti yang diinginkan. } \\
\text { 2. Alur bukti sudah runtut meskipun bukti yang diajukan kurang tepat } \\
\text { yang diakibatkan kesalahan pada ide awal pembuktian }\end{array}$ \\
\hline
\end{tabular}




\begin{tabular}{|c|c|c|}
\hline Aspek & $\begin{array}{l}\text { Persentase } \\
\text { Keberhasilan }\end{array}$ & Tipe-tipe kesalahan \\
\hline & & 3. Alur bukti tidak runtut, tidak ada koherensi pada tiap-tiap langkah. \\
\hline $\begin{array}{l}\text { Pemahaman } \\
\text { terhadap } \\
\text { teorema atau } \\
\text { konsep-konsep } \\
\text { terkait }\end{array}$ & $22,86 \%$ & $\begin{array}{l}\text { 1. Salah dalam menentukan teorema yang digunakan dalam pembuktian } \\
\text { 2. Tidak menguasai konsep dua segitiga saling kongruen }\end{array}$ \\
\hline
\end{tabular}

Dari tabel 2 terlihat bahwa keberhasilan mahasiswa dalam menyelesaiakan masalah pembuktian geometri atas penggunaan sketsa diagram dan tabel sebanyak $28 \%$ dari 35 mahasiswa. Hal tersebut dapat ditunjukan oleh hasil pengerjaan mahasiswa R-29 yang telah benar dan sukses membuktikan masalah seperti tampak dalam gambar 1.

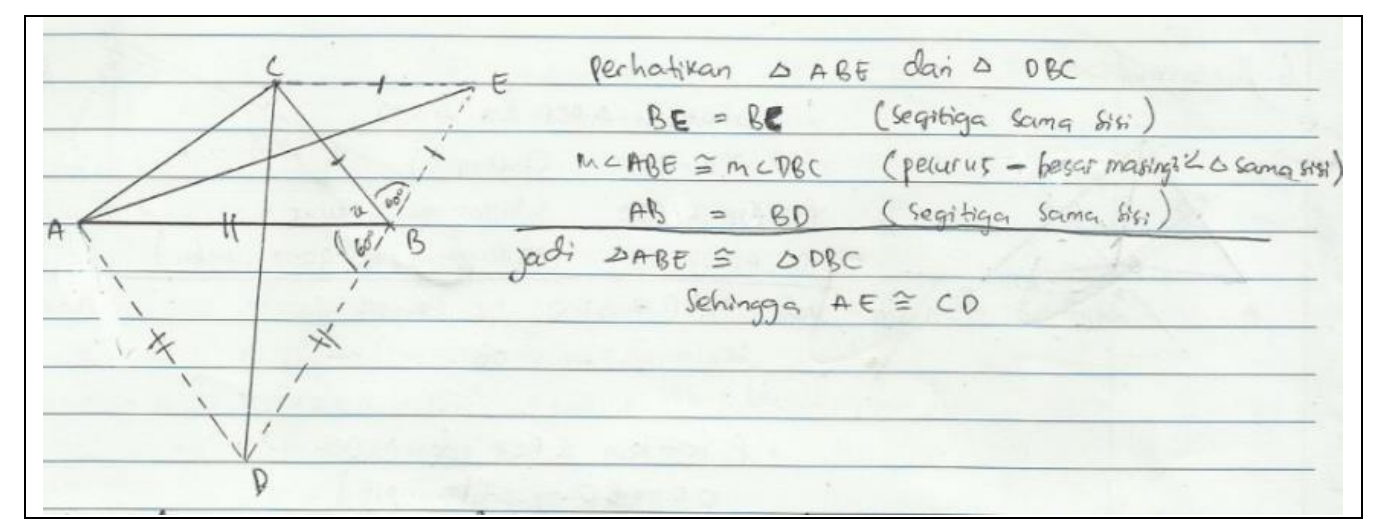

Gambar 1. Sketsa diagram dan Simbol yang dibuat oleh R-29

Pada gambar 1 terlihat R-29 melakukan proses mengkonstruksi sketsa diagram dengan baik. Gambar yang telah dikonstruksi diikuti dengan proses penentuan label geometri yang lengkap sesuai dengan kaidah-kaidah yang ada di materi geometri. Sebagi conotoh, R-29 memberikan label "// (coret dua)" pada dua buah sisi $\triangle A B D$ dan memberikan label "/ (coret satu)" pada dua buah sisi $\triangle B C E$ yang menunjukkan bahwa kedua segitiga tersebut adalah segitiga sama sisi. Hal ini terkesan sederhana, akan tetapi merupakan bagian penting dalam pembuktian geometri. Karena, persepsi mahasiswa akan berpengaruh pada simbol-simbol yang diberikan pada sketsa diagram yang telah dikonstruksi.

Sebaliknya mahasiswa R-6 memulai pembuktian dengan sketsa diagram yang kurang tepat karena tidak menuliskan simbol geometri secara tepat dan tidak merepresentasikan masalah yang akan dibuktikan yang mengakibatkan bukti yang diajukanpun tidak sesuai yang diharapkan. Bahkan R-6 tidak dapat menuliskan buktinya yang artinya tidak mampu menuliskan bukti yang diinginkan. Gambar 2 menunjukan hasil kerja mahasiswa R-6 yang tampak seperti berikut. 


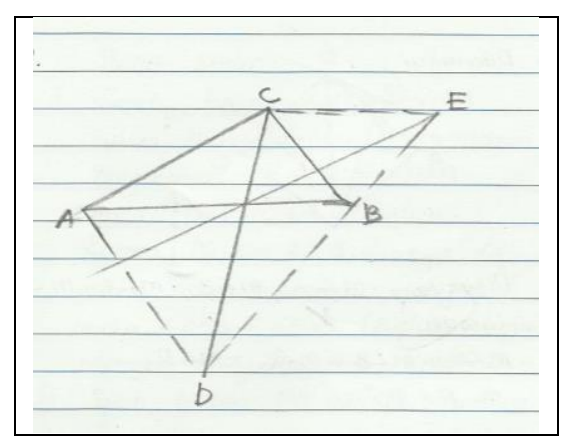

Gambar 2. Sketsa diagram dan label geometri yang dibuat oleh R-6

Pada Tabel 2 terlihat hanya 28,57\% mahasiswa memiliki langkah awal pembuktian secara tepat. Ada beberapa langkah awal yang telah diajukan oleh mahasiswa, sebagai contoh langkah awal yang tepat telah diajukan R-16 seperti tambak pada Gambar 3 berikut.

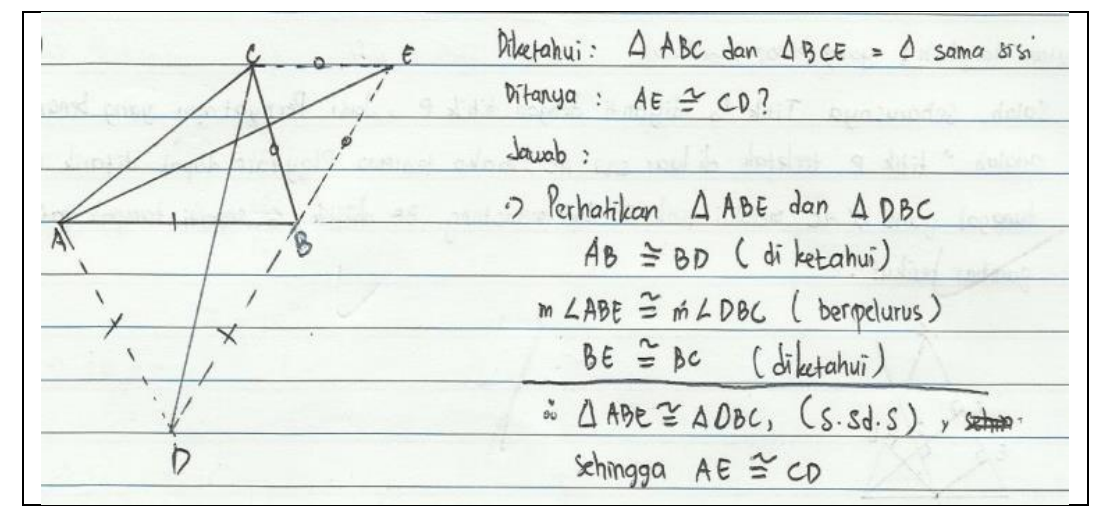

Gambar 3. Langkah awal pada bukti yang diajukan oleh R-16

Gambar 3 menunjukan proses penentuan langkah awal bukti yang tepat yang telah dilakukan oleh R-16. Mahasiswa R-16 memulai langkah awal pembuktian dengan memperlihatkan $\triangle A B E$ dan $\triangle D B C$, yang selanjutnya membuktikan keduanya saling kongruen. Langkah awal yang tepat ini, memberikan dampak yang positif bagi R-16 sehingga dengan mudah untuk menentukan konjektur-konjektur berikutnya yang mengarahkan pada bukti yang diinginkan, meskipun pada dalam memebrikan alasan bahwa $\angle A B E=\angle D B C$ (berpelurus) kurang tepat. Akan tetapi ide tersebut menuju pada bukti yang diinginkan yaitu pada kesimpulan akhir bahwa $A E \cong C D$.

Berbeda dengan R-16, mahasiswa R-25 menentukan langkah awal bukti dengan kurang tepat. Berikut disajikan bukti yang diajukan seperti tampak pada Gambar 4. 


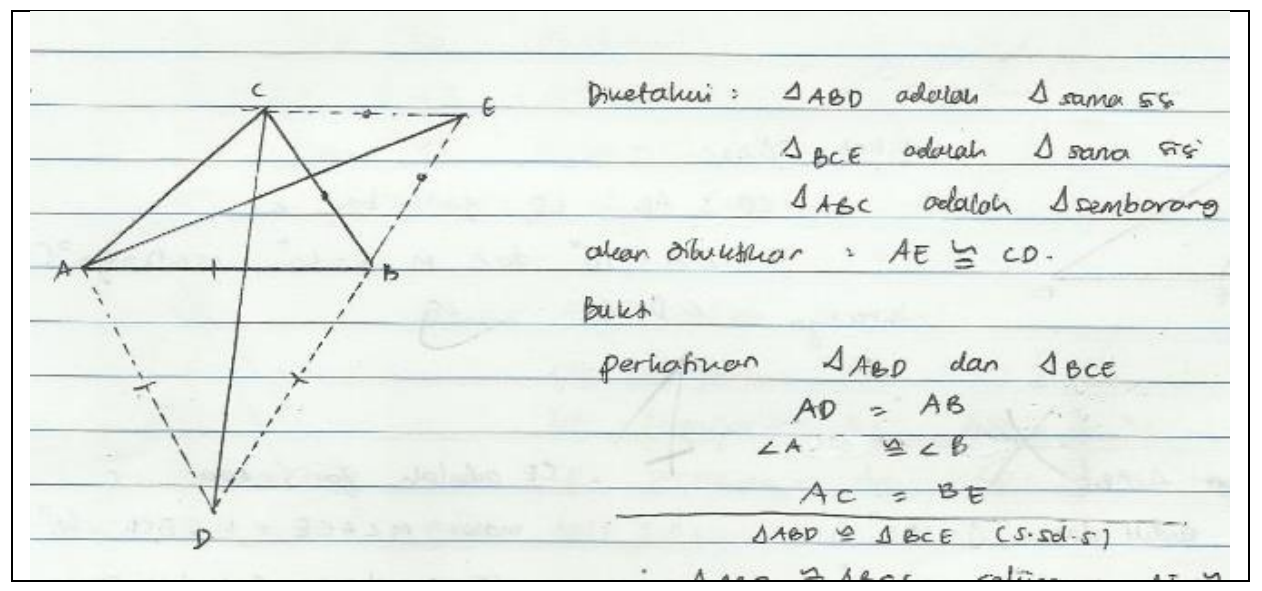

Gambar 4. Langkah awal pada bukti yang diajukan oleh R-25

R-25 dalam menentukan langkah awal dengan menunjukan $\triangle A B D$ dan $\triangle B C E$ yang dilanjutkan dengan mengambil dua buah unsur sisi yaitu segmen AE dan CD. Mahasiswa R-25 mencoba menggunakan konsep dua segitiga saling kongruean, tetapi pada segitiga yang dugunakan dalam proses pembuktian, tidak ada unsur yang akan dibuktikan. Hal tersebut mengindikasikan bahwa M-25 salah dalam melakukan langkah awal proses pembuktian, sehingga mahasiswa M-25 mengajukan bukti yang salah.

Pada tabel 2 terlihat bahwa keberhasilan mahasiswa dalam menentukan konjektur hanya $28,57 \%$ atau ada $71,43 \%$ mahasiswa yang tidak dapat memanfaatkan konjektur untuk proses pembuktian. Pemanfaatan konjektur dengan menuliskan "perhatika $\triangle B A E$ dan $\triangle B A E$ " yang menunjukan bahwa R-10 memiliki konjektur bahwa kedua segitiga tersebut saling kongruen. Gambar 5 memperlihatkan hasil jawaban R-10 terhadap masalah bukti yang telah diajukan.

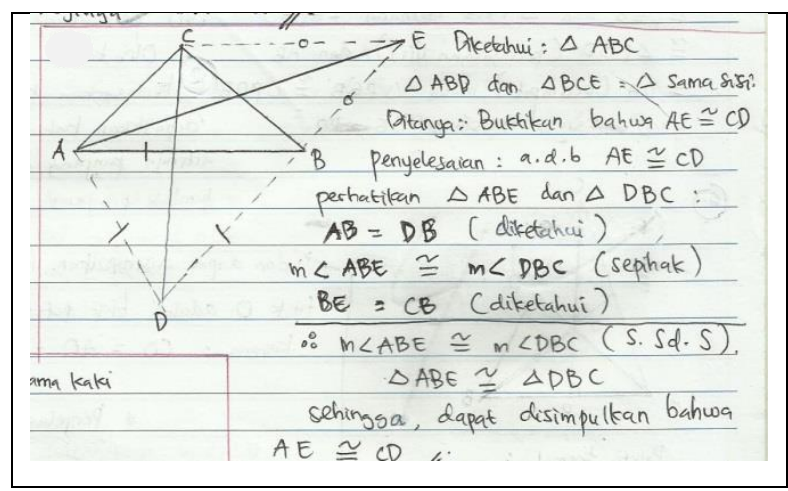

Gambar 5. Bukti yang diajukan oleh R-10

Gambar 5 memperlihatkan konjektur yang diajukan oleh R-10 sudah tepat dan dapat dimanfaatkan dengan baik. Mahasiswa R-10 dalam proses penyelesainya langsung menunjukan adanya keterkaitan antara dua buah segitiga yaitu $\triangle B A E$ dan $\triangle B A E$ yang mengarah pada bukti yang diinginkan. Konjektur tersebut dilanjutkan dengan menunjukan bahwa sisi $\mathrm{AB}=\mathrm{DB}$, 
$\angle A B E \cong \angle D B C$, dan $\mathrm{BE}=\mathrm{CB}$ sehingga menyimpulkan $\triangle B A E \cong \triangle B A E$ (S.Sd.S). Setelah mahasiswa R-10 membuktikan konjekturnya yaitu $\triangle B A E \cong \triangle B A E$, selanjutnya disimpulkan tujuan akhir pembuktian bahwa $A E \cong C D$. Hal tersebut menunjukan bahwa dalam memanfatkan konjektur R-20 sudah mempergunakan dua prinsip dalam pembuktian yaitu menentukan konjektur dan membuktikan konjektur tersebut.

Mengacu pada bukti yang telah disusun pleh R-20, terlihat bahwa dalam proses mengkonstruksi bukti pemanfatan konjektur menjadi kunci penting dalam mengembangkan bukti yang akan disusun. Proses menentukan konjektur yang kemudian dilanjutkan dengan proses membuktikan konjektur tersebut akan menjadi rangkaian pernyataan yang kemudian membentuk bukti yang diinginkan.

Pada tabel 2 terlihat bahwa argumentasi dalam mengkonstruksi bukti geometri mahasiswa masih perlu dioptimalkan. Hal tersebut ditunjukan dengan hanya $25,71 \%$ mahasiswa tepat dalam menyusun argumentasi bukti sesuai dengan postulat dan teorema yang benar. Kesulitan mahasiswa dalam menggunakan argumentasi geometri diantaranya yaitu: 1) argumentasi yang telah disusun tidak disertai alasan logis sehingga terjadi kesalahan bukti dan 2) argumen yang telah disusun tidak ada hubunganya dengan bukti yang dituju. Kesulitan tersebut juga dialami oleh mahasiswa R-34 yang ditunjukan pada Gambar 6 berikut.

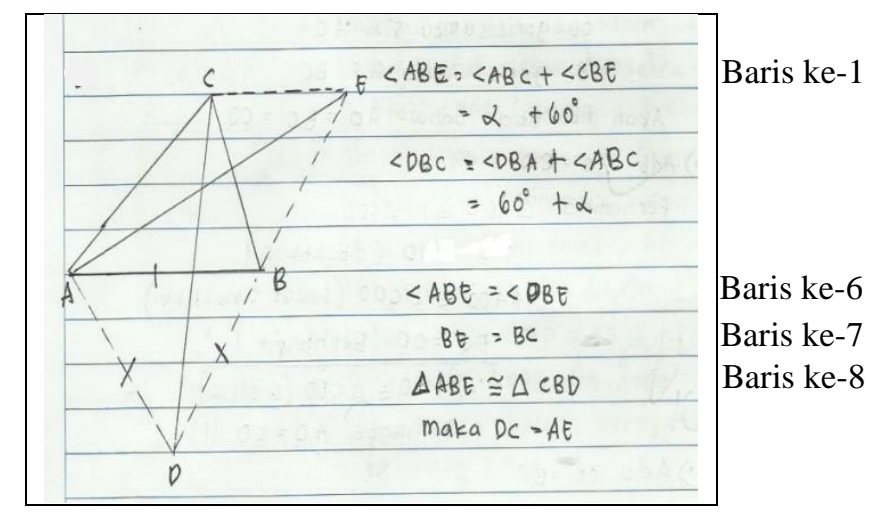

Gambar 6. Bukti yang diajukan oleh R-34

Gambar 6 memperlihatkan bahwa proses pengambilan kesimpulan $\triangle A B E \cong \triangle C B D$ disertai dengan argumen yang keliru dengan memberikan alasan $\triangle A B E \cong \triangle D B C$ dan $\mathrm{BE}=\mathrm{BC}$. Terlihat di baris 6, 7 dan 8, pernyataan M-34 tidak memberikan alasan yang jelas yang tidak terkait langsung dengan bukti yang benar. Hal tersebut menunjukan bahwa argumentasi pada proses mengkonstruksi bukti harus disertai dengan alasan yang logis dan memiliki hubungan satu sama lain dari konjektur yang telah ditetapkan.

Tabel 2 menunjukan bahwa 25,71\% proses alur berpikir yang digunakan mahasiswa runtut mengarah pada bukti yang benar. Pada Gambar 4 terlihat penyelesaian bukti yang 
disajikan oleh R-16 dengan alur pikir yang runtut dan tidak terjadi lompatan logika pada setiap langkah-langkah pembuktianya. Pembuktian diawali dengan mengkonstruksi sketsa diagram lengkap dengan label geometri yang tepat, kemudian menuliskan unsur-unsur yang diketahui dan yang akan dibuktikanSelannjutnya langkah awal bukti dituliskan secara tepat yaitu dengan menggunakan memilih dua segitiga yang saling kongruen. Langkah demi langkah disusun oleh mahasiswa R-16 secara tepat dan saling terkait hingga pada bukti yang dituju yaitu $A E \cong C D$.

Terlihat pada tabel 2 yang menunjukan $22,86 \%$ mahasiswa menguasai teorema dan konsep yang digunakan dalam meyusun bukti. Hal tersebut terlihat dari bukti yang diajukan oleh mahasiswa R-15 yang tampak pada Gambar 7 berikut.

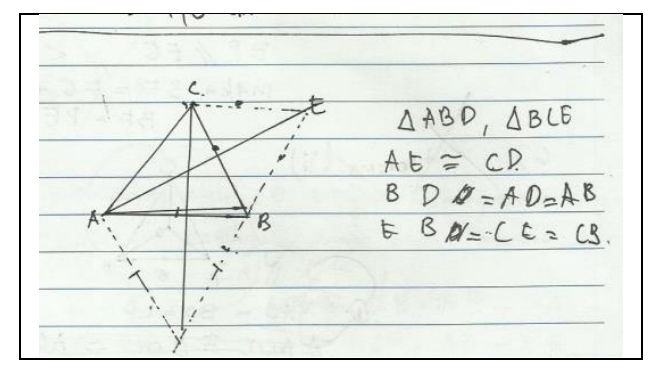

Gambar 7. Bukti yang diajukan oleh M-15

Pada gambar 7 terlihat mahasiswa R-15 tidak paham atas konsep dua segita yang saling kongruen. Tampak R-15 mencoba untuk menuliskan $\triangle B C E, \triangle A B D$ dan menuliskan $A E \cong B D$ , tetapi tidak dapat menuliskan argumetasi yang logis. Langkah-langkah buktipun tidak tersusun secara koheren dan tidak memiliki alur pembuktian yang logis. Kurangnya pemahaman terhadap teorema dan konsep yang terkait dengan bukti yang dituju menjadi penyebab utamanya.

\section{Pembahasan}

Kemampuan mengkonstruksi bukti geometri merupakan syarat mutlak bagi mahasiswa dalam proses pembelajaran geometri di perguruan tinggi, karena kematangan bermatematika salah satu faktor penentunya adalah kemampuan pembuktian (Maarif, Perbowo, Noto \& Harisman, 2019; Mariotti \& Pedemonte, 2019). Prinsip dasar dari mengkonstruksi bukti pada mata kuliah geometri adalah bagaimana mahasiswa menyampaikan ide gagasanya secara runtut sehingga tersusun bukti geometri yang benar. Dalam mengkonstruksi bukti geometri, kiranya perlu memperhatikan beberapa aspek yang mendukung proses pembuktian diantaranya: penggunaan sketsa diagram dan label geometri; pemanfaatan konjektur; langkah awal pembuktian; argumentasi; alur berpikir dan pemahaman terhadap teorema atau konsep-konsep terkait. 


\section{Penggunaan Sketsa Diagram dan Label Geometri}

Pada Tebel 2 terlihat bahwa hasil penelitian menunjukakan bahwa 28\% mahasiswa membuat sketsa diagram dan menggunakan label geometri secara tepat pada bukti yang telah dikonstruksi. Artinya terdapat $72 \%$ mahasiswa yang kurang tepat dalam menggunakan sketsa diagram. Hal tersebut menunjukan betapa pentingnya proses mengkonstruksi diagram dalam proses mengkonstruksi bukti geometri. Hasil penelitian Lindsay (1998) yang mengungkapkan penekanan terhadap latihan membuat demonstrasi diagram terhadap masalah geometri yang akan dibuktuhkan memberikan beberapa interpretasi intuitif dan membantu proses mengkonstruksi bukti. Sejalan dengan Londsay, beberapa hasil penelitian juga mengungkapakan mengkonstruksi sketsa diagram dengan label geometri yang tepat akan memudahkan seseorang dalam proses mengkonstruksi bukti geometri (Maarif, Perbowo, Noto, \& Harisman, 2018; Magajna, 2013).

Beberapa kesalahan yang terjadi dari hasil analisis terhadap jawaban mahasiswa diantaranya: tidak lengkap dalam menentukan label pada sketsa diagram; sketsa diagram tidak mencerminkan dengan informasi yang terdapat dalam masalah yang akan dibuktikan; dan tidak dapat mengkonstruksi sketsa diagram dan label geometri dari masalah yang akan dibuktikan. Beberapa kesalahan-kesalahan tersebut memiliki kesamaan terhadap hasil penelitian yang Maarif dkk, (2019) yang mengungkapkan salah satu hambatan mahasiswa dalam proses pembuktian geometri yaitu kesulitan dalam membuat sketsa diagram dengan notasi geometri ang benar sehingga sulit untuk mengidentifikasi masalah yang akan dibuktikan. Hasil penelitian yang dilakukan oleh Asyhar (2015) menemukan mahasiswa masih mengalami keulitan dalam menerjemahkan gambar atau diagram geometri dalam bentuk pernyataan yang mmengarah pada bukti. Hasil penelitian lain mengungkapkan kesalahan teknis dalam menggambarkan masalah geometri yang akan dibuktikan masih menjadi kendala mahasiswa dalam membuktikan masalah geometri (Yazidah, 2017). Hal itu sejalan dengan hasil penelitian Dimakos dkk yang mengungkapkan bahwa konstruksi gambar menjadi bagian utama dalam mengkonstruksi bukti geometri (Dimakos, Nikoloudakis, Ferentinos, \& Choustoulakis, 2007).

\section{Langkah Awal}

Kualitas bukti geometri selain ditentukan oleh proses mengkonstruksi sketsa diagram yang tepat, juga ditentukan oleh langkah awal dalam menuliskan bukti geometri yang tepat. Tabel 2 menunjukan hasil penelitian yang hanya 28,57\% langkah awal bukti dengan tepat. Hal tersebut menunjukan bahwa penentuan langkah awal mahasiswa masih mengalami kesulitan. 
Kesulitan yang dialami oleh mahasiswa diantaranya: memulai pembuktian dengan mengambil unsur pada sketsa diagram kurang tepat dengan bukti yang dituju; langkah awal bukti sudah benar, akan tetapi terjadi kesalahan dalam mengambil mengambil syarat cukup dua segitiga saling kongruen; dan langkah awal bukti tidak memiliki keterkaitan dengan bukti yang diharapkan pemanfatan konjektur. Kesalahan-kesalahn dalam menentukan langkah awal tersebut harus diminimalisir supaya proses mengkonstruksi bukti berjalan dengan lancar. Pentingnya langkah awal dalam mengkonstruksi bukti geometri sesua dengan hail penelitian yang telah dilakukan oleh Mariotti \& Pedemonte (2019) yang mengunkapkan memulai suatu bukti menjadi bagian penting dalam proses pembuktian karena ide awal suatu bukti akan memunculkan suatu konjektur untuk menentukan langkah berikutnya.

\section{Pemanfaatan Konjektur}

Konjektur dan bukti merupakan elemen kunci dalam proses pembelajaran mengkonstruksi bukti yang kudanya ada pada dua kegiatan yaitu menyataan konjektur dan membuktikan konjektur (Fiallo \& Gutiérrez, 2017). Konjektur harus dimanfaatkan oleh seorang mahasiswa untuk selanjutnya dibuktikan sehingga tersusun langkah-langkah pembuktian yang akan dilakukan. Akan tetapi, hasil penelitian pada tabel 2 menunjukan bahwa 28,57\% mahasiswa dapat menentukan konjektur dengaan tepat yang mengarah pada bukti yang benar. Hal tersebut menunjukan bahwa penentuan konjektur dalam mengkonstruksi bukti geometri masih perlu ditingkatkan. Beberapa kesalahan siswa dalam menentukan konjektur dalam mengkonstruksi bukti diantaranya: konjektur yang diambil kurang tepat; konjektur yang diambil tidak sesuai dengan sketsa diagram yang telah dibuat; dan konjektur sudah tepat, akan tetapi tidak dapat memanfaatkanya untuk menentukan konjektur selanjutnya yang mengarah pada bukti yang diharapkan. Hal tersebut sejalan dengan penelitian yang telah dilakukan oleh Komatsu dan Jones (2019) yang mengungkapakan seseorang yang menentukan konjektur dalam proses pembuktian belum dapat dimanfaatkan secara optimal untuk kemudian membuktikan konjektur berikutnya sehingga langkah bukti tidak tepat.

\section{Argumentasi}

Proses pembuktian akan lebih efektif jika seseorang tepat dalam menentukan konjektur yang selanjutnya menggunakan argumentasi yang logis dalam membuktikan konjektur yang telah ditentukan (Cervantes-Barraza et al., 2020). Hasil penelitian pada Tabel 2 menunjukan $25,71 \%$ mahasiswa tepat dalam menyusun argumentasi bukti sesuai dengan postulat dan teorema yang benar. Hal tersebut menunjukan bahwa argumentasi dalam mengkonstruksi bukti 
geometri mahasiswa masih perlu dioptimalkan. Kesulitan mahasiswa dalam menggunakan argumentasi geometri diantaranya yaitu: argumentasi yang telah disusun tidak disertai alasan logis dan argumen yang telah disusun tidak memiliki koherensi dengan bukti benar. Kesalahan tersebut sejalan dengan penletian Maarif, dkk (2019) yang mengungkapkan dalam mengkonstruksi bukti geometri mahasiswa mengalami kesulitan dalam memilih argumen valid dari konjektur yang dibuat. Hasil penelitian yang telah dilakukan oleh Yazidah, (2017) mengungkapkan mahasiswa dalam mengkonstruksi bukti geometri masih mengalami kesulitan mencari argumen pada langkah pembuktian geometri. Hasil penelitian lain yang dilakukan oleh Asyhar (2015) juga menemukan dalam mengkonstruksi bukti geometri mahasiswa sudah dapat menyusun argumen menggunakan pernyataan yang logis, tetapi argumen yang diberikan belum lengkap sehingga tidak sesuai dengan bukti yang diinginkan.

\section{Alur Berpikir}

Tabel 2 menunjukan hasil penelitian $25,71 \%$ proses alur berpikir yang digunakan mahasiswa runtut mengarah pada bukti yang benar. Artinya masih ada 74,29\% mahasiswa masih belum dapat menuliskan alur pembuktian yang benar. Beberapa kesalahan yang terjadi dalam menentukan alur pembuktian diantaranya: alur bukti sudah runtut, akan tetapi karena ada kesalahan dalam menentukan syarat cukup dua segitiga saling kongruan; alur bukti sudah runtut meskipun bukti yang diajukan kurang tepat yang diakibatkan kesalahan pada ide awal pembuktian; dan alur bukti tidak runtut, tidak ada koherensi pada tiap-tiap langkah. Kesalahan tersebut sesuia dengan hasil penelitian penelitian yang dilakukan oleh Firmasari \& Sulaiman (2019) yang mengunkapkan kekeliriuan dalam membuktiakn salah satunya adalah tidak memahami alur pembuktian.

\section{Pemahaman Terhadap Teorema atau Konsep}

Pemahaman terhadap konsep atau teorema yang akan digunakan dalam proses mengkonstruksi bukti diibaratkan jantung dari proses pembuktian. Langkah awal, penentuan konjektur, proses argumentasi dan menyusun alur bukti yang runtut tidak akan terjadi, jika seseorang tidak paham atas teorema atau konsep-konsep yang digunakan. Kondisi tersebut sesuai dengan temuan penelitian Sommerhoff \& Ufer (2019) yang menyimpulkan bahwa pemahaman seseorang terhadap teorema menjadi modal dasar dalam proses pembuktian matematis. 
Tabel 2 menunjukan 22,86\% mahasiswa menguasai teorema dan konsep yang digunakan dalam meyusun bukti. Kesalahan yang terjadi pada mahasiswa dalam mengkonstruksi bukti yang berkaitan dengan pemahaman terhadap teorema dan konsep diantaranya: salah dalam menentukan teorema yang digunakan dalam pembuktian dan tidak menguasai konsep dua segitiga saling kongruen. Kondisi tersebut sejalan dengan hasil penelitian Yazidah (2017) yang mengungkapkan kesalahan mahasiswa dalam menyusun bukti geometri diakibatkan lemahnya pemahaman awal mahasiswa terhadap bangung geometri, mahasiswa tidak paham terhadap definisi, teorema, dan postulat untuk membuktikan bangun geometri tersebut.

\section{Simpulan}

Kemampuan mengkonstruksi bukti geometri mahasiswa menunjukan bahwa: $28 \%$ mahasiswa membuat sketsa diagram dan menggunakan label geometri secara tepat pada bukti yang telah dikonstruksi; $28,57 \%$ mahasiswa memiliki langkah awal pembuktian secara tepat; $28,57 \%$ mahasiswa dapat menentukan konjektur dengaan tepat yang mengarah pada bukti yang benar; $25,71 \%$ mahasiswa tepat dalam menyusun argumentasi bukti sesuai dengan postulat dan teorema yang benar; $25,71 \%$ proses alur berpikir yang digunakan mahasiswa runtut mengarah pada bukti yang benar; 22,86\% mahasiswa menguasai teorema dan konsep yang digunakan dalam meyusun bukti. Dari hal tersebut, peneliti merekomendasikan untuk penelitian selanjutnya untuk mempergunakan keenam aspek tersebut dalam proses pembelajaran mengkonstruksi bukti atau proses pengembangan instrumen dalam mengkonstruksi bukti geometri.

\section{Referensi}

Arnawa, I. M., Sumarno, U., Kartasasmita, B., \& Baskoro, E. T. (2007). Applying the Apos Theory to improve students ability to prove in elementary abstract algebra. Journal of the Indonesian Mathematical Society, 13(1), 133-148. https://doi.org/10.22342/jims.13.1.80.133-148.

Asyhar, B. (2015). Analisis kemampuan mahasiswa dalam menyelesaikan soal pembuktian tentang isomorfisma grup. Jurnal Tadris Matematika, 2(2). 127-135. https://doi.org/10.21274/jtm.2019.2.2.111-126.

Azrou, N., \& Khelladi, A. (2019). Why do students write poor proof texts? A case study on undergraduates' proof writing. Educational Studies in Mathematics, 102(2), 257-274. https://doi.org/10.1007/s10649-019-09911-9.

Bieda, K. N., Ji, X., Drwencke, J., \& Picard, A. (2014). Reasoning-and-proving opportunities in elementary mathematics textbooks. International Journal of Educational Research, 64, 71-80. https://doi.org/10.1016/j.ijer.2013.06.005.

Cervantes-Barraza, J. A., Hernandez Moreno, A., \& Rumsey, C. (2020). Promoting mathematical proof from collective argumentation in primary school. School Science and Mathematics, 120(1), 4-14. https://doi.org/10.1111/ssm.12379. 
Daguplo, M. S., \& Development, H. R. (2014). How well do you write proof? characterizing students proof - writing skill vis - à - vis van hiele's model in geometrical proving. Journal of Educational and Human Resource Development, 2, 104-114.

Dimakos, G., Nikoloudakis, E., Ferentinos, S., \& Choustoulakis, E. (2007). Developing a proofwriting tool for novice lyceum geometry students. The Teaching of Mathematics, 10(2), 87-106.

Fiallo, J., \& Gutiérrez, A. (2017). Analysis of the cognitive unity or rupture between conjecture and proof when learning to prove on a grade 10 trigonometry course. Educational Studies in Mathematics, 96(2), 145-167. https://doi.org/10.1007/s10649-017-9755-6.

Firmasari, S., \& Sulaiman, H. (2019). Kemampuan pembuktian matematis mahasiswa menggunakan induksi matematika. Journal of Medives: Journal of Mathematics Education IKIP Veteran Semarang, 3(1), 1-9. https://doi.org/10.31331/medivesveteran.v3i1.642.

Harini, L. P. I., \& Oka, T. B. (2016). Penggunaan mind map dalam matematika. Jurnal Matematika, 6(1), 56-67.

Heinze, A., \& Reiss, K. M. (2002). Reasoning and proof: methodological knowledge as a component of proof competence. European Research in Mathematics Education, III, 110.

Hilbert, T. S., Renkl, A., Kessler, S., \& Reiss, K. (2008). Learning to prove in geometry: Learning from heuristic examples and how it can be supported. Learning and Instruction, 18(1), 54-65. https://doi.org/10.1016/j.learninstruc.2006.10.008.

Hodds, M., Alcock, L., \& Inglis Loughborough, M. (2014). Self-explanation training improves proof comprehension. Journal for Research in Mathematics Education, 45(1), 62-101. https://doi.org/10.5951/jresematheduc.45.1.0062.

Isnarto, (2014). Kemampuan konstruksi bukti dan berpikir kritis matematis mahasiswa pada perkuliahan struktur aljabar melalui guided discovery learning pendekatan motivation to reasoning and proving tasks. Disertasi tidak dipublikasikan, Bandung, Universitas Pendidikan Indonesi.

Jones, K. (2010). Proving in geometry. Proceedings of the British Society for Research into Learning Mathematics, 30(2), 62-67.

Komatsu, K., \& Jones, K. (2019). Task design principles for heuristic refutation in dynamic geometry environments. International Journal of Science and Mathematics Education, 17(4), 801-824. https://doi.org/10.1007/s10763-018-9892-0.

Kuusi, T., Mingione, G., \& Nyström, K. (2014). Sharp regularity for evolutionary obstacle problems, interpolative geometries and removable sets. Journal Des Mathematiques Pures et Appliquees, 101(2), 119-151. https://doi.org/10.1016/j.matpur.2013.03.004.

Leech, N. L., \& Onwuegbuzie, A. J. (2007). An array of qualitative data analysis tools: a call for data analysis triangulation. School Psychology Quarterly, 22(4), 557-584. https://doi.org/10.1037/1045-3830.22.4.557.

Lindsay, R. K. (1998). Using diagrams to understand geometry. Computational Intelligence, 14(2), 238-272. https://doi.org/10.1111/0824-7935.00062.

Maarif, S., Perbowo, K. S., Noto, M. S., \& Harisman, Y. (2019). Obstacles in constructing geometrical proofs of mathematics-teacher-students based on Boero's proving model. Journal of Physics: Conference Series, 1315, 012043. https://doi.org/10.1088/17426596/1315/1/012043.

Maarif, S., Wahyudin, Noto, M. S., Hidayat, W., \& Mulyono, H. (2018). Geometry exploration activities assisted with Dynamic Geometry Software (DGS) in a teacher education classroom. Infinity Journal, 7(2), 133-146. https://doi.org/10.22460/infinity.v7i2.p133$\underline{146 .}$. 
Magajna, Z. (2013). Overcoming the obstacle of poor knowledge in proving geometry. CEPS journal, 3(4), 99-116.

Magro, T. D. (2019). On Euclidean diagrams and geometrical knowledge. Theoria 34(2), 255 276. https://doi.org/10.1387/theoria.20026.

Mariotti, M. A., \& Pedemonte, B. (2019). Intuition and proof in the solution of conjecturing $\begin{array}{llll}\text { problems'. } \quad \text { ZDM - } & \text { Mathematics } & \text { Education, 51(5), } & \text { 7577. }\end{array}$ https://doi.org/10.1007/s11858-019-01059-3.

Masters, J. (2010). Automated scoring of an interactive geometry item: A proof-of-concept. Journal of Technology, Learning, and Assessment, 8(7), 1-38.

Michael, P., Gagatsis, C., \& Gagatsis, A. (2013). Geometrical figures in geometrical task solving: an obstacle or a heuristic tool?. Acta Didactica Universitatis Comenianae. Mathematics, 2013(13), 17-32.

Middleton, T. J. (2009). Development of scoring rubrics and pre-service teachers ability to validate mathematical proofs. Digital Library The University Mexico. Diambil dari https://digitalrepository.unm.edu/math_etds/30.

Ningrum, R., \& Mega, T. . (2015). Alur berpikir siswa SMP dalam membuktikan teorema Pythagoras melalui tugas pengajuan soal ditinjau dari perbedaan jenis kelamin. MATHEdunesa Jurnal Ilmiah Pendidikan Matematika, 3(3), 59-66.

Otten, S., Gilbertson, N. J., Males, L. M., \& Clark, D. L. (2014). The mathematical nature of reasoning-and-proving opportunities in geometry textbooks. Mathematical Thinking and Learning, 16(1), 51-79. https://doi.org/10.1080/10986065.2014.857802.

Ozturk, B. M. (2020). Cognitive and metacognitive skills performed by math teachers in the proving process of number theory. Athen Journal of Education, 7(1).1-19.

Pegg, J., Gutiérrez, A., \& Huerta, P. (1998). Assessing reasoning abilities in geometry. New ICMI Studies Series, 5. 275-295.

Reiss, K., \& Renkl, A. (2002). Learning to prove: The idea of heuristic examples. ZDM International Journal on Mathematics Education, 34(1), 29-35. https://doi.org/10.1007/BF02655690.

Sommerhoff, D., \& Ufer, S. (2019). Acceptance criteria for validating mathematical proofs used by school students, university students, and mathematicians in the context of teaching. ZDM, 51(5), 717-730.

Tripathi, P. N. (2020). Exploring the use of deductive logic in geometry AS. International Conference to Review Research in Science, Technology and Mathematics Education (2), 91-100.

Yazidah, N. I. (2017). Analisis kesalahan menyelesaikan soal pembuktian geometri Euclid ditinjau dari gender pada mahasiswa IKIP Budi Utomo Malang. KALAMATIKA Jurnal Pendidikan Matematika, 2(1),
https://doi.org/10.22236/KALAMATIKA.vol2no1.2017pp71-80. 